Comment le mal vient aux hommes

\title{
Entretien avec Philippe Adrien et Luc de Goustine
}

Isabelle Schwartz-Gastine

\section{(2) OpenEdition}

\section{Journals}

Édition électronique

URL : http://journals.openedition.org/shakespeare/1158

DOI : 10.4000/shakespeare.1158

ISSN : 2271-6424

Éditeur

Société Française Shakespeare

Édition imprimée

Date de publication : 1 novembre 1997

Pagination : 209-217

Référence électronique

Isabelle Schwartz-Gastine, "Entretien avec Philippe Adrien et Luc de Goustine », Actes des congrès de la Société française Shakespeare [En ligne], 15 | 1997, mis en ligne le 01 janvier 2007, consulté le 01 mai 2019. URL : http://journals.openedition.org/shakespeare/1158; DOI : 10.4000/shakespeare.1158

Ce document a été généré automatiquement le 1 mai 2019.

(C) SFS 


\section{Entretien avec Philippe Adrien et Luc de Goustine}

Isabelle Schwartz-Gastine 